Wiesław KĄKOL ${ }^{1}$

\title{
LOKATA STRUKTURYZOWANA JAKO ALTERNATYWNA FORMA OSZCZĘDZANIA
}

W niniejszym opracowaniu zaprezentowano problem inwestycji w lokaty strukturyzowane z punktu widzenia zasad ich działania oraz opłacalności. Analizę przeprowadzono na podstawie produktów oferowanych przez polskie instytucje finansowe w latach 2010-2012.

Słowa kluczowe: bankowość, lokata strukturyzowana, oszczędzanie, ryzyko inwestycyjne.

\section{WPROWADZENIE}

Szybki rozwój rynku kapitałowo-pieniężnego w Polsce sprawia, że wzrasta na nim konkurencja. Pojawiają się nowe podmioty, a także nowe produkty finansowe. Konkurencję odczuwają również banki. Ich tradycyjna oferta lokacyjna składająca się z rachunków oszczędnościowych i lokat przestaje być atrakcyjna w porównaniu z innymi możliwościami, jakie obecnie klientom indywidualnym daje rynek. Taka sytuacja sprawia, że banki zaczynają rozszerzać swoją paletę produktów lokacyjnych, kierując się W stronę bankowości inwestycyjnej opartej na instrumentach finansowych rynku kapitałowego. Od kilku lat w ofercie banków znajdują się lokaty strukturyzowane. Banki reklamują je jako bezpieczne produkty o dużym potencjale zysku. W praktyce klient nabywa produkt skomplikowany, którego zysk zależy od spełnienia pewnych z góry założonych warunków rynkowych. Większość takich lokat gwarantuje ochronę wpłaconego kapitału, jednak oszacowanie prawdopodobieństwa osiąnnięcia zysku jest bardzo trudne, nawet dla finansistów.

Celem opracowania jest analiza możliwych konstrukcji lokat strukturyzowanych oraz ich opłacalności dla inwestorów na przykładzie dotychczasowych doświadczeń z rynku polskiego. W pierwszej części artykułu zaprezentowano teoretyczne podstawy budowy oraz funkcjonowania lokat strukturyzowanych. Główny nacisk położono na dokonanie charakterystyki różnych rodzajów opcji wchodzących w skład lokat. W drugiej części opracowania dokonano analizy pięciu wybranych lokat strukturyzowanych pod kątem ich konstrukcji oraz ostatecznych wyników. Wskazano też na zalety i wady tych produktów finansowych w kontekście analizy ich opłacalności w latach 2009-2011. Wnioski końcowe zostały zawarte w podsumowaniu.

\section{CHARAKTERYSTYKA LOKATY STRUKTURYZOWANEJ}

Tradycyjna lokata bankowa to umowa pomiędzy klientem a bankiem, w której klient udostępnia bankowi swoje środki pieniężne (zakłada depozyt) na z góry określony czas, otrzymując w zamian wynagrodzenie w postaci odsetek. Najważniejszymi parametrami lokaty są: czas trwania, sposób i wysokość oprocentowania, częstotliwość wypłaty lub kapitalizacji odsetek. Lokaty tradycyjne mogą mieć termin zapadalności od jednego dnia

${ }^{1}$ Dr Wiesław Kąkol, Zakład Finansów i Bankowości, Wydział Zarządzania, Politechnika Rzeszowska. 
do nawet kilku lat. W większości wypadków możliwe jest automatyczne odnowienie umowy lokaty po upływie terminu zapadalności. Zysk klienta zależy od wysokości oprocentowania oraz częstotliwości kapitalizacji odsetek. Wysokość oprocentowania jest ustalana indywidualnie przez banki i zależy od wielu czynników. Jednak w większości wypadków nie przekracza ona stopy Warsaw Interbank Offered Rate (WIBOR), ponieważ zgromadzone przez klientów pieniądze banki inwestują najczęściej na rynku międzybankowym lub w bezpieczne papiery dłużne. Cała operacja musi być więc opłacalna dla banków, a co za tym idzie, oprocentowanie lokaty jest kalkulowane na niezbyt wysokim poziomie. W wyjątkowych wypadkach wysokość oprocentowania jest wyższa niż na przykład stopa WIBOR, ale zazwyczaj są to lokaty krótkoterminowe i mają za zadanie pozyskać klientów w celu zaproponowania im innych produktów banku. Ostateczny zysk klienta zależy również od częstotliwości kapitalizacji odsetek, czyli częstotliwości dopisywania narosłych na lokacie odsetek do kapitału. Im częstsze są kapitalizacje, tym klient więcej zarabia. Większość banków oferuje lokaty o stałym i zmiennym oprocentowaniu. W wypadku oprocentowania stałego klient już podczas podpisywania umowy lokaty wie, jaki będzie jego zarobek. W wypadku oprocentowania zmiennego wysokość oprocentowania znana jest tylko w pierwszym okresie odsetkowym, natomiast stopa procentowa w kolejnych okresach odsetkowych jest ustalana zgodnie $\mathrm{z}$ określoną $\mathrm{w}$ regulaminie lokaty formułą. Oprocentowanie zmienne jest stosowane $\mathrm{w}$ lokatach o długich terminach zapadalności. Taka konstrukcja lokaty chroni klienta oraz bank przed ryzykiem zmiany stóp procentowych w czasie. Lokaty o oprocentowaniu zmiennym są więc bezpieczniejsze niż te o oprocentowaniu stałym. Wspólną cechą tradycyjnych lokat bankowych jest gwarancja zwrotu zainwestowanego kapitału oraz odsetek narosłych podczas trwania lokaty, przy czym przy oprocentowaniu stałym wielkość zysków jest wiadoma już w chwili zakładania lokaty.

Lokaty strukturyzowane w swojej konstrukcji tylko częściowo przypominają lokaty tradycyjne. Należą one ogólnie do grupy produktów strukturyzowanych. Ich charakterystyczną cechą jest to, że składają się z dwóch części: „bezpiecznej” oraz „ryzykownej”. Ich specyficzna konstrukcja gwarantuje ochronę kapitału, całkowitą lub czesściową, oraz daje możliwość uzyskania dochodu. Jednakże ostateczna wysokość stopy zwrotu nie jest znana w trybie ex ante ${ }^{2}$.

Aby móc lokatę nazwać produktem strukturyzowanym, musi ona spełniać następujące warunki ${ }^{3}$ :

- ochrona kapitału całkowita lub częściowa;

- określony czas trwania danej inwestycji;

- stopa zwrotu zgodna z określoną formuła;

- wbudowany instrument pochodny, na przykład opcja.

Zasada działania lokaty strukturyzowanej jest następująca:

1. kapitał wnoszony przez klienta jest dzielony na dwie części: bezpieczną i ryzykowna;

2. część bezpieczna to 80-90\% wniesionego kapitału. Jest ona najczęściej inwestowana w bezpieczne papiery wartościowe o stałym dochodzie, czyli na przykład obligacje skarbowe lub lokaty tradycyjne stałooporcentowane. Część ta

\footnotetext{
${ }^{2}$ M. Mokrogulski, P. Sepielak, Produkty strukturyzowane w Polsce w latach 2000-2010, KNF, Warszawa 2010, s. 5.

${ }^{3}$ B. Antkiewicz, M. Kalinowski, Innowacje finansowe, CeDeWu, Warszawa 2006, s. 215.
} 
ma za zadanie wygenerować taki zysk, żeby w terminie wykupu klient mógł odzyskać 100\% swojego kapitału. Dlatego też im mniej środków przeznacza się na część bezpieczną, tym dłuższy musi być okres trwania lokaty, żeby zainwestowany kapitał mógł się „odbudować” w 100\%.

3. część ryzykowna to $10-20 \%$ zainwestowanego kapitału. Jest ona inwestowana $\mathrm{w}$ instrumenty pochodne, najczęściej są to opcje na różnego rodzaju instrumenty bazowe. Klient może osiagnąć zysk tylko wtedy, gdy na końcu (lub w pewnych ustalonych okresach) instrument bazowy będzie miał wartość w wyznaczonym w kontrakcie opcyjnym przedziale. W przeciwnym razie kwota zainwestowana w zakup opcji zostaje utracona.

Całą konstrukcję lokaty strukturyzowanej przedstawiono na rysunku 1 . Widać na nim, że środki zainwestowane składają się z części bezpiecznej oraz zysku przez nią wygenerowanego. Zysk natomiast jest uzyskiwany za pomocą ryzykownego instrumentu pochodnego.

Rys. 1. Konstrukcja lokaty strukturyzowanej ze 100-procentową ochroną kapitału

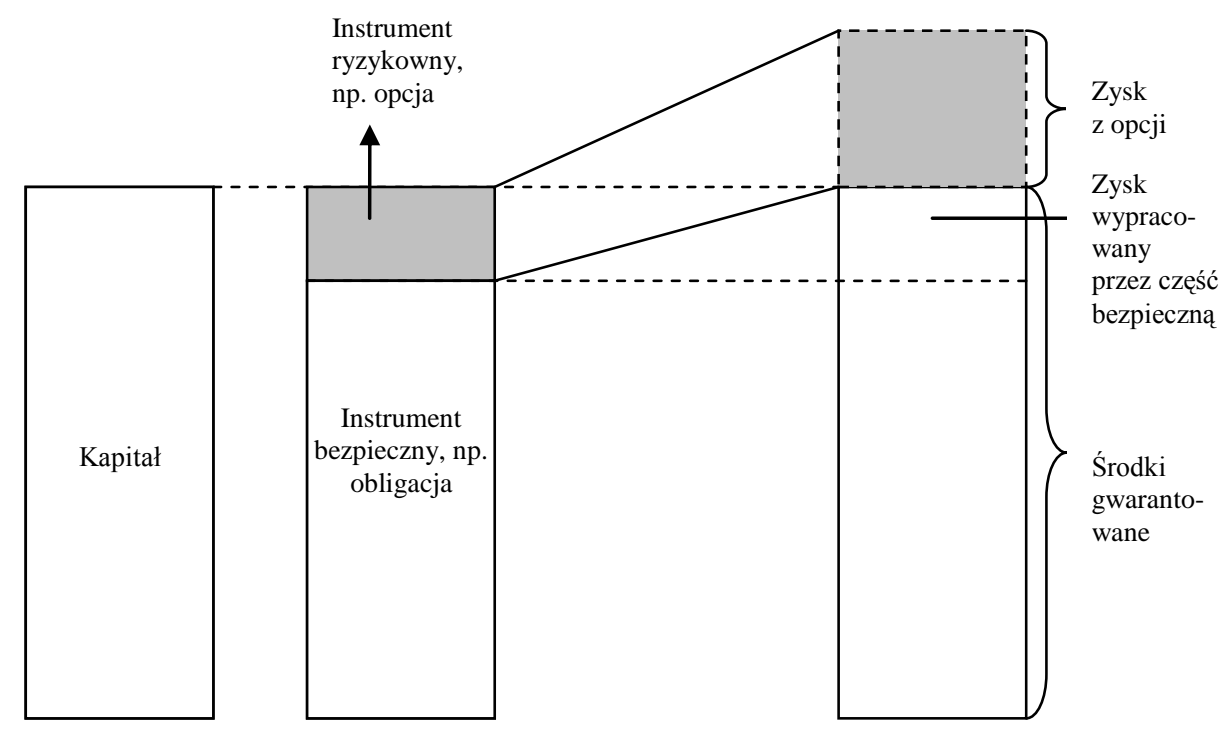

Źródło: opracowanie własne na podstawie: M. Mokrogulski, P. Sepielak, Produkty strukturyzowane w Polsce w latach 2000-2010, KNF, Warszawa 2010, s. 13.

Większość lokat strukturyzowanych daje $100 \%$ gwarancji kapitału, co oznacza, że klient po zakończeniu trwania lokaty ma zagwarantowany zwrot zainwestowanych środków finansowych. Zdarzają się jednak lokaty, które nie gwarantują całości kwoty, lecz tylko na przykład 70-80\%. Powodzenie przedsięwzięcia zależy w tym wypadku wyłącznie od tego, ile uda się zarobić na części ryzykownej. Zysk może być tym większy, im więcej środków zostanie przeznaczonych na część ryzykowną. Nacisk na maksymalizację zysków oznacza więc albo wydłużenie czasu trwania lokaty, albo rezygnację $\mathrm{z}$ gwarancji zainwestowanego kapitału w całości. W praktyce najczęściej 
wybiera się pierwszy wariant ze względu na to, że tego typu produkty są dedykowane w większości tym samym klientom, którzy nabywają tradycyjne lokaty. Są to klienci nieakceptujący ryzyka przynajmniej w ujęciu nominalnym, a więc widmo utraty chociaż części inwestycji zupełnie zniechęcałoby ich do założenia lokaty strukturyzowanej.

Najbardziej newralgiczny element lokaty to jej część ryzykowna. To od niej zależy w ostatecznym rozrachunku wysokość zysków dla klienta. Część ta opiera się na instrumencie pochodnym i jest to zazwyczaj opcja kupna. Opcje są obecnie bardzo powszechnym instrumentem finansowym. Opcja kupna daje jej posiadaczowi, zwanemu nabywca, prawo, ale nie obowiązek do nabycia danego dobra (instrumentu bazowego) po z góry określonej cenie. Prawo to może być zrealizowane w dniu wygaśnięcia opcji (opcja europejska) lub w każdym innym dniu od daty zawarcia kontraktu opcyjnego do daty wygaśnięcia włącznie (opcja amerykańska). Opcja zostaje zrealizowana, jeśli przewidywana przez nią cena instrumentu bazowego jest lepsza niż cena oferowana na rynku w danym czasie. Zysk nabywcy opcji jest równy różnicy między ceną rynkową a ceną realizacji opcji. Jeżeli realizacja opcji wywoływałaby stratę dla nabywcy, to może on odstąpić od jej wykonania, tracąc kwotę, za którą opcja została zakupiona - tak zwaną premię opcyjną 4 .

Instrumentami bazowymi dla opcji mogą być:

- $\quad$ indeksy giełdowe (o zasięgu globalnym jak i mniej popularne);

- indeksy sektorowe;

- $\quad$ strategie, których celem jest zarabianie w każdych warunkach;

- $\quad$ ceny akcji spółek (pojedynczych lub koszyków akcji);

- $\quad$ ceny towarów (metale, nośniki energii, ceny płodów rolnych oraz

indeksy i strategie surowcowe);

- $\quad$ kursy walut (lokalnych i światowych);

- $\quad$ wysokość stóp procentowych (krótko- i długoterminowych).

Opcje dają inwestorom nowe możliwości niedostępne w wypadku tradycyjnych instrumentów. Dzięki nim można czerpać korzyści w razie na przykład wzrostu cen instrumentu bazowego przy z góry określonej - maksymalnej - stracie. W wypadku niekorzystnych zmian cen na rynku nabywca opcji po prostu jej nie wykona, tracąc jedynie premię zapłaconą za nabycie takiej opcji. Sytuację tę przedstawiono na rysunku 2.

Przyjmując, że cena zakupu opcji wynosi C (jest to kwota równa części ryzykownej lokaty strukturyzowanej), a cena wykonania wynosi $\mathrm{X}$, nabywca zrealizuje opcję w każdym wypadku, gdy cena instrumentu bazowego przekroczy wartość ceny wykonania $X$. Im cena instrumentu bazowego będzie wyższa od ceny wykonania $X$, tym większy zysk dla inwestora. Natomiast jeżeli cena instrumentu bazowego nie przekroczy ceny wykonania $\mathrm{X}$, nabywca opcji zrezygnuje z jej wykonania i poniesie stratę w wysokości C.

\footnotetext{
${ }^{4}$ J. Hull, Kontrakty terminowe i opcje, WIG Press, Warszawa 1998, s. 325.
} 


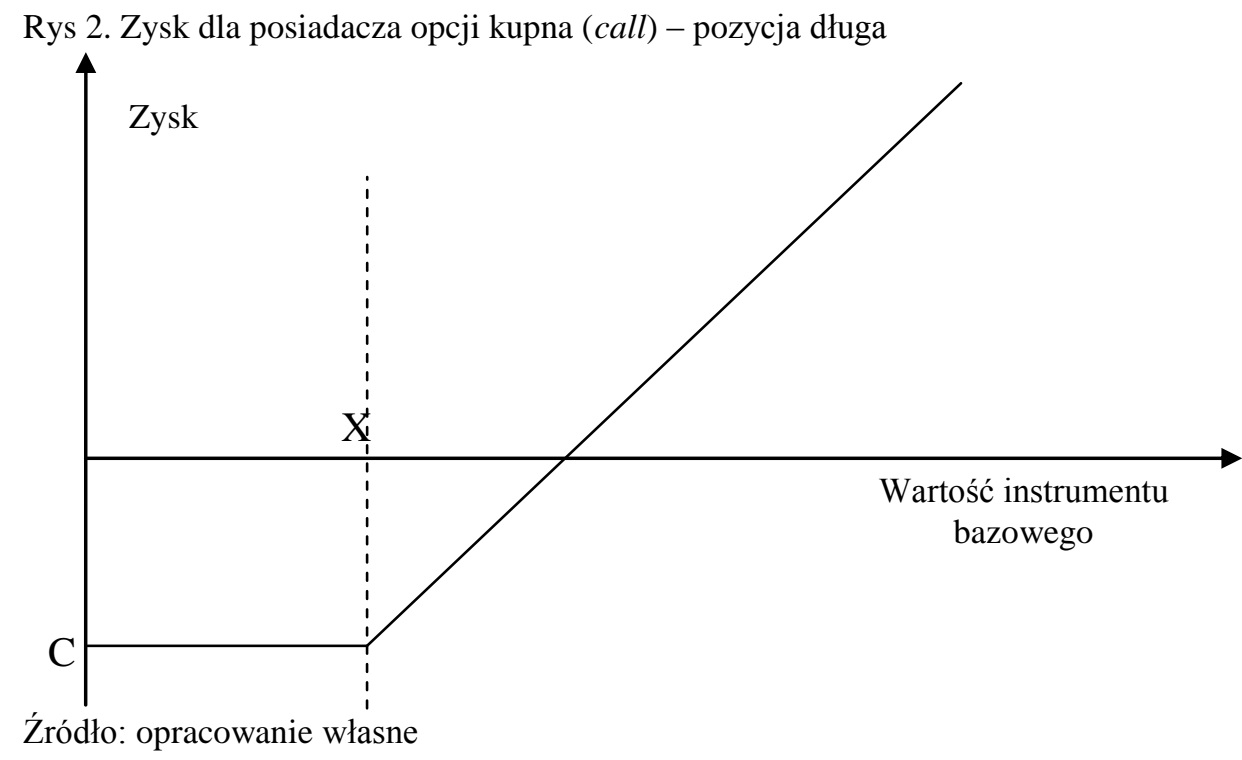

Zaletą opcji jest też to, że można je wykorzystać do zarabiania nie tylko na wzrostach wartości instrumentu bazowego, ale także na jego spadkach. W takim wypadku mówi się, że inwestor ma opcję kupna, ale w pozycji krótkiej. Znaczy to, że będzie on zarabiał zawsze wtedy, gdy cena wykonania $\mathrm{X}$ będzie wyższa od rzeczywistej ceny $\mathrm{z}$ dnia wykupu. Wykres zysków w takim wypadku pokazano na rysunku 3.

Rys. 3. Zysk dla posiadacza opcji kupna (call) - pozycja krótka

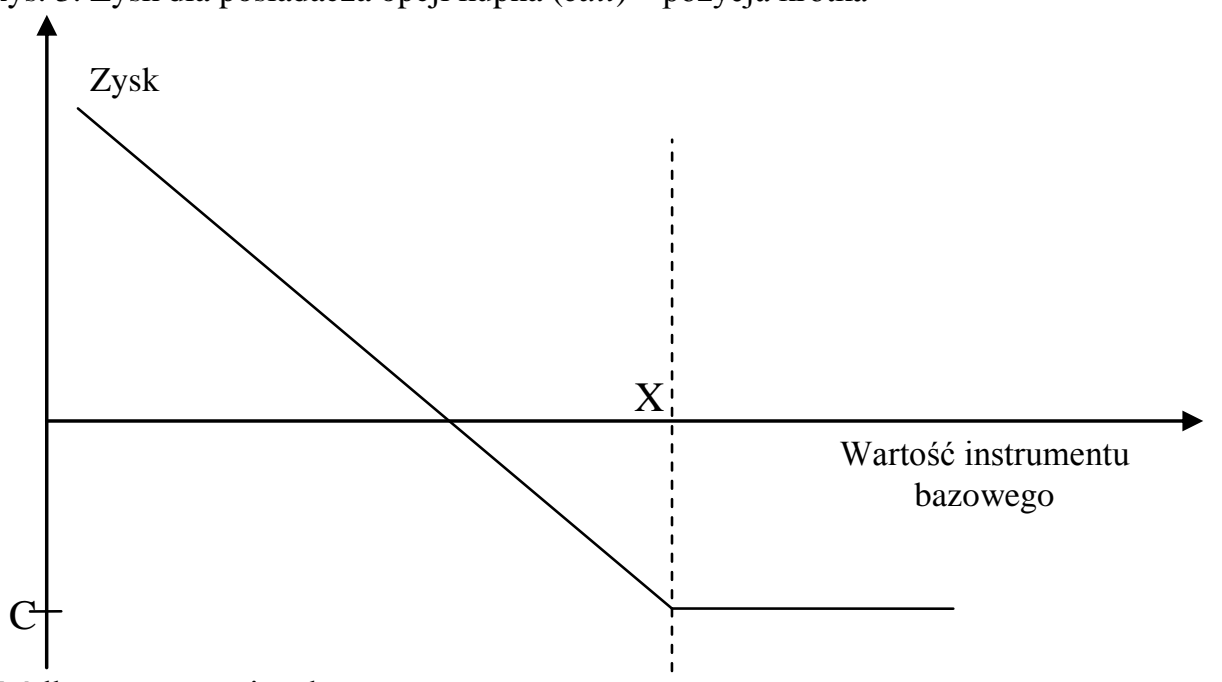

Źródło: opracowanie własne 
Przedstawione strategie opcji call bardzo często są modyfikowane. Jedną z przyczyn jest wysoka cena zakupu standardowej opcji (vanilla). Na przykład jak podaje portal structus.pl (20.10.2012), cena opcji call przy pozycji długiej na indeks WIG20 to około $21 \%$ wartości kapitału zainwestowanego w lokatę strukturyzowaną w skali roku, a więc z każdych zainwestowanych 100 zł, 21 zł musiałoby być przeznaczone na zakup opcji. W takiej sytuacji nie jest możliwe, żeby pozostałe 79 zł ulokowane w obligacjach lub lokatach po roku czasu dało $100 \mathrm{zl}$, a więc nie mogłaby być zapewniona gwarancja zwrotu całości kapitału. Dlatego w praktyce instytucje oferujące lokaty strukturyzowane często korzystaja z dodatkowych modyfikacji obniżających cenę opcji, ale niestety kosztem zmniejszenia prawdopodobieństwa osiagnięcia zysku. Bardzo często wykorzystuje się opcje z bariera typu knock-out. Działa ona podobnie jak zwykła opcja call, ale ma $\mathrm{z}$ góry określone ograniczenie. Jeżeli cena instrumentu bazowego osiagnie poziom ograniczenia, wtedy inwestor traci zainwestowany kapitał. Czyli na przykład jeżeli w sytuacji pokazanej na rysunku 2 zostanie ustawiona bariera na poziomie $\mathrm{X}+$ $30 \%$, wtedy inwestor będzie zarabiał, jeżeli cena instrumentu bazowego w dniu wykupu opcji znajdzie się $\mathrm{w}$ przedziale od $\mathrm{X}$ do $\mathrm{X}+30 \%$. W pozostałych wypadkach inwestor straci kwotę premii opcyjnej w wysokości -C. Taki zabieg w oczywisty sposób ogranicza prawdopodobieństwo sukcesu, a także znacznie obniża cenę opcji (na przykład dla WIG20 opcja knock-out z 30-procentową barierą kosztowałaby tylko 1,3\% kapitału). Dlatego w praktyce bardzo często pojawiają się produkty strukturyzowane, które mają ściśle określony zakres wartości instrumentu bazowego niezbędny do uzyskania stopy zwrotu właśnie ze względu na zastosowanie opcji knock-out.

Rozważania te dotyczyły opcji europejskich, czyli takich, których rozliczenie następuje $\mathrm{w}$ terminie wykupu. Bardzo często jednak w produktach strukturyzowanych stosowane są opcje azjatyckie, których zysk zależy od tego, jak wartość instrumentu bazowego będzie się kształtowała również $\mathrm{w}$ jej trakcie. Zysk inwestora będzie w takim wypadku wypadkową zachowywania się wartości instrumentu bazowego w kolejnych określonych okresach, na przykład miesięcznych. Takie opcje są popularne ze względu na to, że ich cena zakupu jest zazwyczaj o $30-40 \%$ niższa od opcji europejskich, ale też prawdopodobieństwo osiagnięcia zysku jest mniejsze.

Kolejnym dosyć popularnym rozwiązaniem w lokatach strukturyzowanych jest zastosowanie tak zwanych opcji binarnych. Polegają one na tym, że ich zysk jest z góry określony, a jego wypłata zależy od spełnienia zawartego w umowie warunku. Na przykład opcja wypłaca $10 \%$ zysku, pod warunkiem że wartość indeksu WIG20 wzrośnie $\mathrm{w}$ stosunku do poziomu $\mathrm{z}$ dnia zawarcia transakcji. W przeciwnym wypadku inwestor oczywiście traci premię opcyjną. Opcje takie mogą być stosowane również z barierami typu knock-out $t^{5}$.

Ogólna zasada konstrukcji produktu strukturyzowanego polega na tym, że im większe jest prawdopodobieństwo zysku, tym cena opcji jest oczywiście wyższa. Im więcej jest natomiast warunków ograniczających, tym cena opcji będzie niższa. W wypadku lokat o krótkim czasu trwania i pełnej ochronie kapitału opcja zastosowana w cześci ryzykownej musi być tania, a co za tym idzie, prawdopodobieństwo jej realizacji jest małe i zysk bardzo niepewny. Ponadto nawet jeżeli bank decyduje się na standardową opcję typu call przedstawioną na rysunku 2 lub 3, to bardzo często ogranicza poziom partycypacji klienta w zysku, po to żeby w wypadku odniesienia sukcesu pokryć koszty

\footnotetext{
${ }^{5}$ E. Wiśniewska, Giełdowe instrumenty pochodne, CeDeWu, Warszawa 2007, s. 165.
} 
gwarancji kapitału oraz otrzymać marżę zysku. Dlatego też nieodłącznym parametrem lokat strukturyzowanych jest poziom partycypacji w zyskach. Jeżeli ma on wartość niższą niż 100\%, to oznacza, że bank będzie zabierał część zysku z realizacji opcji dla siebie. Możliwości konstrukcji produktu strukturyzowanego jest więc wiele, ale zawsze towarzyszy im zasada proporcjonalności zysków do poziomu ryzyka. Oznacza to, że przy pełnej gwarancji kapitału nie można liczyć na ponadprzeciętne zyski, co potwierdzają wyniki już zakończonych lokat przedstawione w kolejnym punkcie.

\section{ANALIZA WYBRANYCH LOKAT STRUKTURYZOWANYCH NA RYNKU POLSKIM}

W Polsce po raz pierwszy zaoferowano lokatę strukturyzowaną dostępną dla klientów prywatnych w 2000 roku. Bankiem, który zaproponował taką ofertę, był BZ WBK SA. Czas trwania tej lokaty wynosił 3 lata. Bank zainwestował większość w polskie obligacje skarbowe, a pozostałą część w zabezpieczające transakcje swapowe, czyli opcje azjatyckie $^{6}$. Kolejne lata to bardzo szybki wzrost liczby produktów strukturyzowanych, w tym lokat na polskim rynku. Obecnie praktycznie każdy bank oferuje taką lokatę.

Do analizy w ramach niniejszego opracowania wybrano trzy produkty, w których instrumentem bazowym był indeks WIG20 oraz jeden bazujący na kursach walut i jeden opierający się na inwestycji w złoto.

W roku 2010 mBank zaproponował swoim klientom lokatę strukturyzowaną pod nazwą Wielka 20 -tka ${ }^{7}$. Był to dwuletni produkt, w którym instrumentem bazowym był indeks WIG20. Maksymalny możliwy zysk oszacowano na 34,55\% (17,27\% rocznie). Lokata mogła wypłacać zysk, jeśli kurs czerwcowych kontraktów na WIG20 w dniu obserwacji końcowej byłby wyższy od tego z dnia obserwacji początkowej o więcej niż $10 \%$ :

- jeśli X wyniesie więcej niż 10\%, ale nie więcej niż 50\%, zysk wyniesie iloraz X pomniejszonego o $10 \%$ i wartości $110 \%$ przemnożony przez współczynnik partycypacji;

- jeśli X wyniesie więcej niż 50\%, zysk wyniesie iloczyn współczynnika partycypacji i wartości $10 \%$.

Współczynnik partycypacji ustalono na poziomie 105\%. Lokata gwarantowała 100procentową ochronę kapitału. Rozkład zysków przedstawiono na wykresie 1.

\footnotetext{
${ }^{6}$ Wspótczesna bankowość detaliczna, red. A. Szelagowska, CeDeWu, Warszawa 2010, s. 166-167.

${ }^{7}$ Dane na podstawie informacji portalu structus.pl (dostęp: 20 X 2012)
} 
Wykres 1. Rozkład zysków dla lokaty Wielka 20-tka

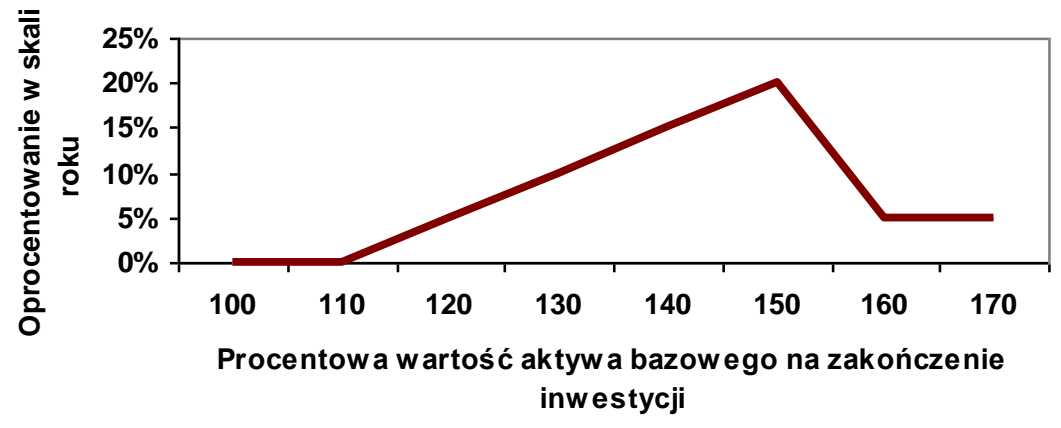

Źródło: opracowanie własne na podstawie danych mBanku.

Lokata ta jest przykładem zastosowania opcji z barierą, po której przekroczeniu zyski drastycznie spadają. W rzeczywistości lokata zakończyła się w czerwcu 2012 r. niepowodzeniem. Kontrakty na WIG20 nie przekroczyły nawet minimalnego zakładanego wzrostu na poziomie $110 \%$. Lokata kusiła więc dużymi potencjalnymi zyskami, ale warto zauważyć, że maksymalny podawany zysk $(34,55 \% \mathrm{w}$ skali 2 lat) był możliwy tylko w wypadku osiagnnięcia przez kontrakty wzrostu na poziomie $150 \%$. Zastosowany wąski przedział zysków (110-150\% wzrostu instrumentu bazowego) na pewno dawał korzyść bankowi w postaci niskiej ceny opcji, ale klient otrzymał produkt $\mathrm{z}$ małym prawdopodobieństwem uzyskania zysków.

W roku 2011 klienci Kredyt Banku mogli skorzystać z Lokaty Strukturyzowanej $\mathrm{XXXI}^{8}$. W odróżnieniu od poprzednio omawianej lokata Kredyt Banku miała sześciomiesięczny okres zapadalności i oparto ją na założeniu o stabilności indeksu WIG20 w tym okresie. Lokata zapewniała klientom 100\% zwrotu kapitału i dodatkowo ewentualną premię w wysokości 4,5\% (9\% w skali roku), w wypadku gdy indeks WIG20 utrzyma się przez cały czas trwania lokaty w przedziale pomiędzy 2550-2950 pkt. Część ryzykowną stanowiła więc opcja binarna $\mathrm{z}$ dwiema barierami. W czasie subskrypcji indeks WIG20 oscylował $w$ granicach 2700-2800 pkt, ale dokładnie pierwszego dnia trwania lokaty spadł poniżej poziomu 2550 pkt, co oznaczało, że klienci musieli zadowolić się wyłącznie zwrotem kapitału po 6 miesiącach. Regulamin lokaty przewidywał jednak możliwość jej zerwania, ale wiązało się to z uiszczeniem prowizji od $3 \%$ do $1 \% \mathrm{w}$ zależności od momentu jej zerwania. Taki mechanizm jest stosowany w większości lokat.

Kolejny produkt, na którego konstrukcję warto zwrócić uwagę, to Lokata WIGor IV $\mathrm{BG} \dot{Z}^{9}$. Jest to dwuletni produkt strukturyzowany zakładający umiarkowany wzrost notowań indeksu WIG20, z maksymalnym zyskiem równym $42 \%$ (21\% rocznie). W

${ }^{8}$ Dane na podstawie informacji portalu structus.pl (dostęp: 20 X 2012)

${ }^{9}$ Dane na podstawie informacji portalu analizy.pl (dostęp: 20 X 2012) 
lokacie zastosowano opcję azjatycką z barierą na poziomie $160 \%$ wartości początkowej indeksu. Na koniec okresu inwestycji klient otrzyma zwrot, jeśli:

- $\quad$ przez cały okres inwestycji bariera nie zostanie naruszona, a wartość końcowa indeksu będzie wyższa od wartości początkowej, to premia będzie równa iloczynowi współczynnika partycypacji (70\%) i uśrednionej stopy zwrotu $\mathrm{z}$ indeksu;

- bariera zostanie naruszona, to premia będzie równa $15 \%(7,5 \%$ w skali roku) niezależnie od dalszego zachowania się indeksu;

- bariera nie zostanie naruszona, a wartość końcowa nie będzie wyższa od wartości początkowej, premia będzie równa $0 \%$.

Jak wynika z zapisów, do obliczeń premii bierze się średnią arytmetyczną stopy zwrotu z kolejnych 12 odczytów w terminach ustalonych regulaminem lokaty. Ostatecznie lokata dała stope zwrotu na poziomie $0,53 \%$ za dwa lata czyli $0,26 \%$ w skali roku. W tym wypadku zadziałał pierwszy wariant formuły na zysk, gdyż WIG20 oscylował w okolicach 2300-2400 pkt. Niestety był to za mały wzrost, żeby uzyskać satysfakcjonującą stopę zwrotu. Dodatkowo na uwagę zasługuje tylko 70-procentowy współczynnik partycypacji klienta w zyskach z tytułu zwiększonej stopy zwrotu.

Odmienną specyfikę ma Lokata Strukturyzowana EUR Złoty Plus, oferowana przez Bank Zachodni WBK, której termin zapadalności upłynął 21 sierpnia $2012 \mathrm{r}^{10}$. Był to sześciomiesięczny produkt strukturyzowany zakładający spadek kursu EUR/PLN według Narodowego Banku Polskiego z maksymalnym zyskiem równym 6\% (12\% w skali roku) i pełną ochroną kapitału. Formuła wypłaty odsetek przedstawiała się następująco:

- $\quad 3,5 \%$, pod warunkiem że kurs EUR/PLN z dnia obserwacji końcowej znajdować się będzie $\mathrm{W}$ prawostronnie domkniętym przedziale, którego granicami są wartość początkowa pomniejszona o 0,20 PLN i wartość początkowa pomniejszona o 0,10 PLN lub w prawostronnie domkniętym przedziale, którego granicami są wartość początkowa pomniejszona o 0,40 PLN i wartość początkowa pomniejszona o 0,30 PLN.

- $\quad 6 \%$, pod warunkiem że kurs EUR/PLN z dnia obserwacji końcowej znajdować się będzie $\mathrm{w}$ prawostronnie domkniętym przedziale, którego granicami są wartość początkowa pomniejszona o 0,30 PLN i wartość początkowa pomniejszona o 0,20 PLN.

Na uwagę zwraca tutaj wykorzystanie złożenia 2 opcji binarnych z barierami. Warto zauważyć, że przedziały wahań kursów określono bardzo wąsko, a co za tym idzie, ryzyko nieotrzymania odsetek było dosyć duże. W wypadku tej lokaty jednak klienci zarobili 3,5\% (7\% w skali roku), ponieważ spełnił się pierwszy scenariusz formuły.

Ostatnia z omawianych lokat to Lokata Inwestycyjna Czas Złota dla klientów BRE Banku $^{11}$. Trwała od lipca 2009 do lipca 2011 r. Część ryzykowna stanowiła tu opcja na cenę złota. Możliwy zysk został ustalony na $20 \%$ (10\% w skali roku). Jego osiagnięcie było obwarowane następującym warunkiem: w dniu końcowej obserwacji aktywo bazowe (London PM Gold Fixing) będzie na poziomie wyższym lub równym 120\% wartości początkowej. W przeciwnym razie inwestor otrzymuje $100 \%$ zainwestowanego kapitału. Ostatecznie klienci zarobili maksymalną kwotę, czyli 20\% w skali 2 lat. Należy jednak

${ }^{10}$ Dane na podstawie informacji portalu analizy.pl (dostęp: 20 X 2012)

${ }^{11}$ Dane na podstawie informacji portalu structus.pl (dostęp: 20 X 2012) 
wspomnieć, że minimalna wpłata wynosiła 25 000zł, a prowizję za ewentualne zerwanie lokaty ustalono malejąco od $12,5 \%$ do $0 \% \mathrm{w}$ zależności od terminu wyjścia z inwestycji.

Przedstawione przykłady lokat pokazują, jak bardzo zróżnicowane są to produkty, a także skomplikowane. Osiągnięcie zysku zależy od spełnienia nieraz bardzo ścisłych warunków, co sprawia, że prawdopodobieństwo sukcesu nie jest zbyt duże.

\section{ZALETY I WADY LOKAT STRUKTURYZOWANYCH}

Do najważniejszych zalet lokat strukturyzowanych można zaliczyć różnorodność oferowanych instrumentów bazowych. Bardzo często lokata opiera się na instrumentach bazowych niedostępnych dla inwestora indywidualnego. Wykorzystanie opcji sprawia, że można zarabiać nie tylko na wzrostach wartości instrumentu bazowego, ale także na jego spadkach. Kolejną ważną zaletą lokat strukturyzowanych jest gwarancja ochrony wpłaconego kapitału, co jest powodem traktowania tych produktów przez wielu klientów banków jako bezpiecznych i chroniących przed dużą zmiennością rynku. Zaletą jest też dość wysoka oczekiwana stopa zwrotu w porównaniu z tradycyjną lokatą. Należy jednak mieć świadomość, że nie zawsze będzie ona mogła być osiagnięta. Jak podaje strona structus.pl, opierając się na danych Open Finance, średnia stopa zwrotu z produktów strukturyzowanych osiągnęła najwyższy poziom w Polsce w pierwszej połowie 2011 r. i wyniosła 4,88\% w skali roku. Niestety już w drugim półroczu 2011 średnia ta spadla do $1,66 \%$. W latach $2009-2010$ było to w granicach $3 \%$ rocznie $^{12}$. Wyniki te pokazują, że lokaty strukturyzowane, chociaż z pozoru mają duży potencjał, w praktyce nie spełniają oczekiwań klientów. Średnie stopy zwrotu wskazują, że nawet przy pełnej ochronie kapitału klient otrzymuje mniej niż na zwykłych lokatach. Zdarzają się jednak lokaty dopracowane, w których bank dba nie tylko o swoje konto, ale także o satysfakcję klienta.

Jeżeli chodzi o wady lokat strukturyzowanych, trzeba zwrócić szczególną uwagę na to, że zainwestowane $\mathrm{w}$ te produkty pieniądze są zamrożone na czas trwania lokaty, a przedterminowe wyjście nie tylko pozbawia zysków, ale także kończy się uiszczeniem „karnej” prowizji dochodzącej nawet do $20 \%$ zainwestowanego kapitału. Ponadto do wad należy zaliczyć skomplikowaną konstrukcję produktu strukturyzowanego, zwłaszcza w części ryzykownej. Tylko nieliczni klienci są w stanie naprawdę zrozumieć sposób funkcjonowania formuły zysku, nie wspominając już o umiejętności przewidzenia przyszłej wartości instrumentu bazowego i świadomego podjęcia na tej podstawie decyzji o zakupie produktu.

\section{PODSUMOWANIE}

Oferta lokat strukturyzowanych oferowanych przez instytucje finansowe w Polsce stale się powiększa. Nadal jest to jednak wczesne stadium rozwoju. Oferowane produkty są lokowane na rynku jako bardzo bezpieczna forma oszczędzania, dająca w perspektywie ponadprzeciętny zysk w porównaniu ze zwykłą lokatą. W praktyce mniej spostrzegawczy klient nabywa taki produkt sugerując się wysoką, oczekiwana stopą zwrotu. Warunki brzegowe otrzymania zysku są dla niego już mniej zrozumiale. Należy pamiętać że w Polsce rynek kapitałowy i wszelkiego rodzaju instrumenty z nim związane takie jak akcje, obligacje pojawiły się dopiero około dwadzieścia lat temu. Instrumenty pochodne

\footnotetext{
${ }^{12}$ Dane na podstawie artykułu: M. Krasoń, Wyniki struktur: dawno nie było tak źle, www.structus.pl (dostęp: 9 III 2012).
} 
zadomowiły się na giełdzie jeszcze później co oznacza że przeciętny klient banku ma o nich niewielkie pojęcie. Nie jest w stanie w racjonalny sposób zrozumieć ich działania więc podejmowane przez niego decyzje są wynikiem impulsu, sugestii reklamy lub pracownika banku a nie świadomego wyboru. Niestety, sytuację tę wykorzystują banki przygotowując oferty o małym prawdopodobieństwie sukcesu. Koszty nabycia opcji są wtedy małe ale perspektywa zysku niewielka. W wielu przypadkach klient po prostu jest kuszony gwarancją kapitału oraz maksymalną możliwą do osiagnnięcia stopą zwrotu, najczęściej nie zaprząta sobie głowy pytaniem, jak duże jest prawdopodobieństwo zysku, i traktuje lokatę strukturyzowaną jak grę hazardową. Do takich spostrzeżeń prowadzi analiza rynku lokat strukturyzowanych w latach 2009-2011. Tylko około 30\% zakończyło się sukcesem, a średnie stopy zwrotu były na bardzo niskim poziomie nawet w porównaniu z tradycyjną lokatą. Banki próbują się chronić przed krytyka twierdząc, że klient jest nieprzygotowany i gdyby był w stanie akceptować wyższe ryzyko (na przykład ochronę kapitału na poziomie $80 \%$ a nie $100 \%$ ) wtedy większą część środków mogłyby przeznaczać na zakup opcji o większym prawdopodobieństwie sukcesu. Prawdopobnie taka właśnie jest droga rozwoju tego typu formy inwestowania, gdyż klient musi zrozumieć, że ponadprzeciętny zysk jest możliwy wtedy gdy pojawia się adekwatne do niego ryzyko. Przed polskim rynkiem lokat strukturyzowanych jest więc jeszcze daleka droga do doskonałości, biorąc pod uwage $\mathrm{z}$ jednej strony rzetelność instytucji finansowych i z drugiej świadomość klientów.

\section{LITERATURA}

[1] Antkiewicz B., Kalinowski M., Innowacje finansowe, CeDeWu, Warszawa 2006.

[2] Hull J., Kontrakty terminowe i opcje, WIG Press, Warszawa 1998.

[3] Mokrogulski M., Sepielak P., Produkty strukturyzowane w Polsce w latach 2000 2010. KNF, Warszawa 2010.

[4] Wiśniewska E., Giełdowe instrumenty pochodne, CeDeWu, Warszawa 2007.

[5] Współczesna bankowość detaliczna, red. Szelagowska A., CeDeWu, Warszawa 2010.

\section{STRUCTURED INVESTMENT AS AN ALTERNATIVE FORM OF SAVING}

The content of this paper is to present the problem of investments in structured bank deposits from the point of view of their performance and profitability. The analysis was carried out on the basis of Polish products offered by financial institutions in 2010-2012.

Keywords: banking, structured investment, saving, investment risk. 